\title{
ANALISIS NORMATIF UNDANG-UNDANG NOMOR 14 TAHUN 2005 SEBAGAI IMPLEMENTASI PERLINDUNGAN TENAGA PENDIDIK (Studi Kasus Penganiayaan Guru SMAN 1 Torjun Sampang Jawa Timur)
}

\author{
Muhlis Fahdiar Sembiring \\ Dosen STKIP Budidaya Binjai
}

\begin{abstract}
Educators are an important role in the formation of human resources as a nation's strength in fortifying themselves in cognitive, affective, and psychomotor concepts. The success of a nation does not escape the role of educators in the equitable development of knowledge and technology. Competitiveness is so high as the development of globalization requires human resources to always be able to develop both in terms of hard skills and soft skills. Based on this, educators are expected to have competence in the application of the learning and teaching process. Legal events that occur in this study are not only the responsibility of educational institutions, but the factors of the family are very influential on the pattern of child development, because the family is the first place and place where children spend more time in the family environment. The way students are applied by parents is also very influential on children's attitudes. Parenting that tends to spoil also shapes the attitude of children who are accustomed to what they want to be fulfilled and with such a pattern of life the child does not learn to control emotions and not learn to manage themselves Law enforcement is a process that is essentially the implementation of directors which involves making decisions that are not strictly regulated by the rule of law but have elements of personal judgment. Conceptually, the core and meaning of law enforcement lies in harmonizing the relationships of values described in solid rules and attitude to act as a series of final stages of value translation, to create, give birth and maintain the peace of life.
\end{abstract}

Keywords : Law Number 14 Year 2005, Protection Implementation, Teacher.

\section{PENDAHULUAN}

\section{A. Latar Belakang}

Guru adalah pendidik profesional dengan tugas utama mendidik, mengajar, membimbing, mengarahkan, melatih, menilai, dan mengevaluasi peserta didik pada pendidikan anak usia dini jalur pendidikan formal, pendidikan dasar, dan pendidikan menengah. ${ }^{1}$ Sementara Dosen adalah pendidik profesional dan ilmuwan dengan tugas utama mentransformasikan, mengembangkan, dan

\footnotetext{
${ }^{1}$ Lihat Undang-Undang Nomor 14 Tahun 2005 Pasal 1 Ayat (1).
} 
menyebarluaskan ilmu pengetahuan, teknologi, dan seni melalui pendidikan, penelitian dan pengabdian kepada masyarakat. ${ }^{2}$

Tenaga pendidik merupakan salah satu peran yang penting dalam pembentukan sumber daya manusia sebagai kekuatan bangsa dalam membentengi diri dalam konsep kognitif, afektif, dan psikomotorik. Keberhasilan suatu bangsa tak luput dari peran tenaga pendidik dalam pemerataan pembangunan secara pengetahuan dan teknologi.

Daya saing yang begitu tinggi seiring perkembangan globalisasi yang menuntut sumber daya manusia untuk selalu mampu berkembang baik dari sisi hard skills maupun soft skills. Berdasarkan hal demikian maka tenaga pendidik diharapkan untuk memiliki kompetensi dalam penerapan pada proses belajar dan mengajar.

Selain itu tenaga pendidik tidak hanya memberikan informasi terbaru yang berkaitan dengan materi yang diajarkan tetapi juga motivasi kepada peserta didik guna meningkatkan kesadaran akan pentingnya pendidikan dalam menghadapi perkembangan globalisasi dan MEA saat sekarang ini.

Paradigma yang berkelanjutan dalam dunia pendidikan dari masa ke masa adalah peningkatan kualitas sumber daya manusia yang mengalami fluktuasi dengan berbagai kecenderungan baik karena faktor internal maupun eksternal dari sisi peserta didik.

Minimnya kecerdasan spiritual dan intelektual dari peserta didik juga mempengaruhi pelaksanaan proses belajar mengajar yang selalu menjadi kendala dalam penerapannya. Etika dan moral yang belum secara baik dikemas oleh tenaga pendidik sebagai materi yang dalam implementasinya menjadi salah satu indikator keberhasilan dalam pembentukan sumber daya manusia yang kompeten baik secara intelektual maupun spiritual.

Kemampuan untuk menyaring perkembangan secara informasi melalui berkembangnya teknologi oleh peserta didik yang belum mampu menyikapi hal tersebut dan disikapi kembali dengan pandangan oleh peserta didik secara dangkal

${ }^{2}$ Ibid., Ayat (2). 
tanpa melihat dampaknya secara menyeluruh terhadap faktor internal dan eksternal secara masiv.

Peristiwa penganiayaan yang terjadi di SMAN 1 Torjun oleh murid kepada guru (SAMPANG, KOMPAS.com) ${ }^{3}$ merupakan dilematika pendidikan. Peran Tenaga Pendidik dan Orang tua serta lingkungan peserta didik sangatlah penting dalam menyikapi peristiwa tersebut.

\section{B. Rumusan Masalah}

Berdasarkan latar belakang masalah yang telah diuraikan sebelumnya, maka penulis merumuskan beberapa hal yang akan dikaji dalam jurnal ini, yaitu :

1. Bagaimana penerapan Undang-Undang Nomor 14 Tahun 2005 dalam konteks normatif?

2. Bagimana pandangan stake holder, orang tua, dosen, dan guru sebagai tenaga pendidik dalam menyikapi problematika pendidikan berdasarkan peristiwa hukum di SMAN 1 Torjun Sampang Jawa Timur?

\section{Metode Penelitian}

Metode pendekatan yang digunakan adalah yuridis-normatif, dengan jenis penelitian dogmatik, bentuk penelitian perskriptif hubungan hukum. Spesifikasi penelitian ini yaitu deskriptif analitis.

Metode pengumpulan data yang digunakan melalui metode library research (kepustakaan) dengan menguji bahan dokumen dan bahan pustaka yang digunakan dalam penelitian ini. Data dianalisis secara kualitatif normatif, meneliti dengan jalan menafsirkan dan membangun pernyataan yang terdapat dalam dokumen per-undang-undangan.

Metode analisis kualitatif, dibangun berdasarkan data sekunder yang berupa teori, makna dan substansinya dari berbagai literatur, peraturan perundangundangan, dan data primer yang diperoleh dari wawancara, pengamatan dan studi kepustakaan, kemudian dianalisis dengan normatifnya undang-undang, teori dan pendapat pakar yang berkaitan, sehingga didapat kesimpulan tentang pandangan menyikapi problematika pendidikan di masa yang akan datang.

\footnotetext{
${ }^{3}$ https://regional.kompas.com/read/2018/02/03/10041991/penganiayaan-guru-oleh-siswa-disampang-begini-kronologinya, diakses tanggal 03 April 2018.
} 


\section{PEMBAHASAN}

\section{A. Penerapan Undang-Undang Nomor 14 Tahun 2005 Dalam Konteks Normatif}

Dalam melaksanakan perannya guru mempunyai, kedudukan, fungsi, dan tujuan dalam implementasi proses belajar mengajar, yakni :

a. Guru mempunyai kedudukan sebagai tenaga profesional pada jenjang pendidikan dasar, pendidikan menengah, dan pendidikan anak usia dini pada jalur pendidikan formal yang diangkat sesuai dengan peraturan perundang-undangan.

b. Pengakuan kedudukan guru sebagai tenaga profesional sebagaimana dimaksud pada ayat (1) dibuktikan dengan sertifikat pendidik ${ }^{4}$

c. Dosen mempunyai kedudukan sebagai tenaga profesional pada jenjang pendidikan tinggi yang diangkat sesuai dengan peraturan perundangundangan.

d. Pengakuan kedudukan dosen sebagai tenaga profesional sebagaimana dimaksud pada ayat (1) dibuktikan dengan sertifikat pendidik. ${ }^{5}$

e. Kedudukan guru sebagai tenaga profesional sebagaimana dimaksud dalam Pasal 2 ayat (1) berfungsi untuk meningkatkan martabat dan peran guru sebagai agen pembelajaran berfungsi untuk meningkatkan mutu pendidikan nasional. ${ }^{6}$

f. Kedudukan dosen sebagai tenaga profesional sebagaimana dimaksud pada Pasal 3 ayat (1) berfungsi untuk meningkatkan martabat dan peran dosen sebagai agen pembelajaran, pengembang ilmu pengetahuan, teknologi, dan seni, serta pengabdi kepada masyarakat berfungsi untuk meningkatkan mutu pendidikan nasional. ${ }^{7}$

g. Kedudukan guru dan dosen sebagai tenaga profesional bertujuan untuk melaksanakan sistem pendidikan nasional dan mewujudkan tujuan

\footnotetext{
${ }^{4}$ Loc. Cit., Pasal 2.

${ }^{5}$ Ibid., Pasal 3.

${ }^{6}$ Ibid., Pasal 4.

${ }^{7}$ Ibid., Pasal 5.
} 
pendidikan nasional, yaitu berkembangnya potensi peserta didik agar menjadi manusia yang beriman dan bertakwa kepada Tuhan Yang Maha Esa, berakhlak mulia, sehat, berilmu, cakap, kreatif, mandiri, serta menjadi warga negara yang demokratis dan bertanggung jawab. ${ }^{8}$

Pasal 14 Undang-Undang No 14 Tahun 2005 menyebutkan hak guru yaitu :

1. memperoleh penghasilan di atas kebutuhan hidup minimum dan jaminan kesejahteraan sosial.

2. mendapatkan promosi dan penghargaan sesuai dengan tugas dan prestasi kerja.

3. memperoleh perlindungan dalam melaksanakan tugas dan hak atas kekayaan intelektual.

4. memperoleh kesempatan untuk meningkatkan kompetensi.

5. memperoleh dan memanfaatkan sarana dan prasarana pembelajaran untuk menunjang kelancaran tugas keprofesionalan.

6. memiliki kebebasan dalam memberikan penilaian dan ikut menentukan kelulusan, penghargaan, dan/atau sanksi kepada peserta didik sesuai dengan kaidah pendidikan, kode etik guru, dan peraturan perundangundangan.

7. memperoleh rasa aman dan jaminan keselamatan dalam melaksanakan tugas.

8. memiliki kebebasan untuk berserikat dalam organisasi profesi.

9. memiliki kesempatan untuk berperan dalam penentuan kebijakan pendidikan.

10. memperoleh kesempatan untuk mengembangkan dan meningkatkan kualifikasi akademik dan kompetensi.

11. memperoleh pelatihan dan pengembangan profesi dalam bidangnya.

Peningkatan kompetensi guru sebagai tenaga pendidik merupakan hal yang tidak mudah untuk dilakukan. Keikutsertaan guru dalam berbagai kegiatan yang dilakukan baik berupa pelatihan, seminar, dan kegiatan lainnya yang

\footnotetext{
${ }^{8}$ Ibid., Pasal 6.
} 
mendukung peningkatan kualitas sumber daya manusia sebagai tenaga pendidik haruslah dibarengi dengan pengetahuan dan pemahaman yang baik sehingga mampu untuk menyampaikan kembali kepeserta didik agar hasilnya yang dicapai sesuai dengan harapan.

Peristiwa hukum yang terjadi dalam penelitian ini tidak hanya merupakan tanggung jawab faktor lembaga pendidikan, akan tetapi faktor dari keluarga sangat berpengaruh terhadap pola perkembangan anak, karena keluarga adalah tempat pertama dan tempat dimana anak lebih banyak menghabiskan waktu di lingkungan keluarga. Cara didik yang diterapkan oleh orang tua juga sangat berpengaruh terhadap sikap anak. Pola asuh yang cenderung memanjakan juga membentuk sikap anak yang sudah terbiasa dengan apa yang dia inginkan terpenuhi dan dengan pola kehidupan yang demikian si anak tidak belajar untuk mengendalikan emosi dan tidak belajar untuk mengelola dirinya. Dan pola orang tua yang emosianal akan membentuk persepktif pada anak bahwa si anak kurang dikehendaki akan menimbulkan dampak psikologi pada anak. ${ }^{9}$

Peristiwa Hukum yang terjadi dapat dikategorikan kedalam tindak pidana. Pengertian tindak pidana dalam Kitab Undang-Undang Hukum Pidana (KUHP) dikenal sebagai dengan istilah strafbaarfeit dan dalam kepustakaan tentang hukum pidana sering mempergunakan delik, sedangkan pembuat UndangUndang merumuskan suatu UndangUndang mempergunakan istilah peristiwa pidana atau perbuatan pidana atau tindakan pidana. ${ }^{10}$

Jonkers merumuskan bahwa "Tindak pidana sebagai peristiwa pidana yang diartikannya sebagai suatu perbuatan yang melawan hukum (wederrechttelijk) yang berhubungan dengan kesengajaan atau kesalahan yang dilakukan oleh orang yang dapat dipertanggungjawabkan". ${ }^{11}$

Rasionalitas Pasal 14 Ayat (7) Undang-Undang Nomor 14 Tahun 2005 menyebutkan, "memperoleh rasa aman dan jaminan keselamatan dalam

\footnotetext{
9 Tri Lestari Utami, Kekerasan Dalam Dunia Pendidikan,http://jurnalilmiahtp2013.blogspot.co.id/2013/12/kekerasan-dalam-duniapendidikan.html, diakses tanggal 03 April 2018.

${ }^{10}$ Amir Ilyas, Asas-Asas Hukum Pidana, Yogyakarta, Rengkang Education Yogyakarta dan Pukap Indonesia, 2012, Hal. 20.

${ }^{11}$ Adami Chazawi, Pelajaran Hukum Pidana I, PT Raja Grafindo Persada, Jakarta, 2001, Hal. 75.
} 
melaksanakan tugas". Hal demikian tak luput dari kenyamanan tenaga pendidik dalam penyampaian materi dan hal-hal yang berkaitan dengan ilmu pengetahuan dimana merupakan bagian esensial terhadap situasi yang kondusif pada ruang ajar dan lingkungan formal pendidikan. Dapat disimpulkan bahwa kondusifitas merupakan salah satu bagian yang perlu diperhatikan baik dari pihak lembaga pendidikan formal maupun pemerintah sebagai jaminan bahwa guru sebagai tenaga pendidik dilindungi dan dijamin keselamatan baik jiwa dan raga dalam melaksanakan tugas, fungsi, dan kedudukannya.

Aktivitas peserta didik dilingkungan internal dan eksternal tidak mampu dilakukan pengawasan secara intensif. Hal tersebut dikarenakan terbatasnya waktu dan kesempatan pihak internal dan eksternal dari peserta didik dalam melakukan upaya tersebut. Adakalanya peserta didik melakukan aktivitas sosial dengan teman-temannya yang terkadang melampaui batas kewajaran sebagai individu yang intelek. Unsur-unsur teknologi dan media yang menyajikan informasi yang belum mampu disaring oleh peserta didik secara tidak langsung berdampak pada perilaku kesehariannya, salah satunya unsur kekerasan.

Ross juga menyarankan tentang social aggression atau kekerasan tak langsung yang ditandai dengan cara menakut-nakuti korban, mengintimidasi, dan dengan cara mengisolasi korban dari lingkungan sosial. Bentuk pengisolasian ini dilakukan dengan berbagai cara termasuk penyebaran gossip, penolakan untuk bersosialisasi dengan korban, bullying terhadap orang yang akan bersosialisasi dengan korban, dan mengkritik cara korban berpakaian serta bentuk lain termasuk ras dari korban, agama, dan cacat tubuh dari korban. Ross menguraikan lebih lanjut bentuk-bentuk kekerasan tak langsung yaitu dengan cara yang halus dan lebih ke arah verbal, seperti memanggil namanya, perlakuan diam, berargumen pada penyerahan kepada yang lain, memanipulasi, gossip yang salah, membohong, rumor, rumor yang salah, staring (tatapan), giggling (terkikih-kikih, tertawa genit), laughing (menertawakan) korban dengan menyampaikan kata-kata tertentu sebagai pemicu reaksi suatu kejadian masa lalu serta berpura-pura. ${ }^{12}$

$\begin{array}{lrrr} & \text { Turmudi, Mengenali Kekerasan Dalam Pendididikan Dan Upaya } & \text { Meniadakannya Atau } \\ \text { Memperkecil } & \text { Resiko } & \text { Tindak } & \text { Kekerasan, }\end{array}$ 
Dalam sebuah tulisan diungkapkan mengenai rukun yang mengacu pada cara bertindak untuk menghilangkan tanda-tanda ketegangan dalam masyarakat atau pribadi sehingga hubungan sosial tetap kelihatan selaras dan baik, unsurunsur yang menimbulkan perselisihan dan keresahan, diupayakan untuk disingkirkan. ${ }^{13}$

Penegakan hukum sebagai suatu proses yang pada hakikatnya merupakan penerapan direksi yang menyangkut membuat keputusan yang tidak secara ketat diatur oleh kaidah hukum akan tetapi mempunyai unsur-unsur penilaian pribadi. Secara konsepsional, maka inti dan arti penegakan hukum terletak pada kegiatan menyerasikan hubungan nilai-nilai yang terjabarkan di dalam kaidah-kaidah yang mantap dan sikap tindak sebagai rangkaian penjabaran nilai tahap akhir, untuk menciptakan, melahirkan dan mempertahankan kedamaian pergaulan hidup. ${ }^{14}$

\section{B. Pandangan Stake Holder, Orang Tua, Dosen, dan Guru Sebagai Tenaga} Pendidik Dalam Menyikapi Problematika Pendidikan Berdasarkan Peristiwa Hukum di SMAN 1 Torjun Sampang Jawa Timur

Rabukit Damanik, M.Pd mengatakan bahwa perbuatan yang terjadi oleh murid kepada guru terhadap kasus hukum di SMAN 1 Torjun Sampang Jawa Timur adalah tidak wajar. Faktor lingkungan dalam hal media yang secara langsung diaplikasikan dalam kehidupan sehari-hari dalam aspek kekerasan. Minimnya materi akhlak yang dibekali oleh lembaga pendidikan formal yang mengakibatkan tidak adanya harmonisasi antara guru dan murid sebagai dampak terjadinya kekerasan. Adapun kekerasan itu muncul dari guru yang memunculkan rasa ketersinggungan siswa hingga berdampak konflik. Hal tersebut dapat diantisipasi bila konsep pendidikan diterapkan sebagaimana mestinya. Bahwa

http://file.upi.edu/Direktori/FPMIPA/JUR._PEND._MATEMATIKA/19610112 87031TURMUDI/F12-Final-Draft-Kekerasan_dalam_Pendidikan-Turmudi.pdf, diakses tanggal 03 April 2018.

${ }^{13}$, Hari Poerwanto. 2010. Kebudayaan dan Lingkungan dalam Perspektif Antropologi. ogyakarta: Pustaka Pelajar. Hal. 222.

${ }^{14}$ Soerjono Soekanto, Faktor-Faktor Yang Mempengaruhi Penegakan Hukum, PT.Rajagrafindo Persada, Jakarta, 2012, Hal. 5. 
pendidikan adalah suatu usaha sadar untuk membimbing dan menolong siswa untuk menumbuhkembangkan kompetensi ; kognitif, afektif, dan psikomotorik. Kata kunci sehingga terjadinya konflik dalam lingkungan formal di sekolah sebagai kasus yang terjadi terletak pada koridor kompetensi afektif. Dimana kompetensi afektif mencakup masalah etika yang didalamnya terdapat unsur moral. Bila hal tersebut terlaksana dengan baik dalam sisi konsep pendidikan yang benar maka peristiwa tersebut dapat dihindari. Pemahaman perkembangan peserta didik dimasing-masing tingkat satuan pendidikan dalam hal ini yaitu pada satuan tingkat pendidikan dasar guru wajib menyayangi siswanya, pada tingkat satuan pendidikan menengah identik pujian dari berbagai hal yang dilakukan, sementara untuk tingkat satuan pendidikan atas lebih condong pada diskusi dalam mencapai tujuan yang diharapkan. ${ }^{15}$

Drs. Partoyo, HS mengatakan bahwasanya perbuatan guru pada umumnya secara prinsip adalah mendidik. Guru merupakan tonggak kekuatan dari suatu bangsa. Dampak globalisasi yang terus berkembang yang tidak dapat disaring oleh siswa dalam menerapkan yang diperoleh melalui pengetahuan dan teknologi yang terus menerus berkembang. Pengaruh Narkoba dan pergaulan yang terlalu bebas sangat berdampak besar pada karakter siswa. Dalam peristiwa diatas peran keluarga sangatlah besar dalam membentuk karakter siswa. Menghindari pergaulan yang negatif sebagai antisipasi dalam aspek kekerasan. ${ }^{16}$

Dr. Hadi Widodo, MA mengatakan peristiwa yang terjadi adalah tidak ideal. Kesalahan dalam betuk apapun seorang guru harus tetap dihormati, dimana guru merupakan representatif orang tua di lingkungan sekolah. ${ }^{17}$

Surya Wibawa, MH mengatakan pendidikan moral dan agama sangatlah penting dalam membekali pribadi siswa. Metode pembelajaran yang diterapkan haruslah sifatnya mencerdaskan, mendewasakan baik terhadap aspek kognitif, afektif, dan psikomotorik. Kompetensi guru juga perlu ditingkatkan dalam proses

\footnotetext{
${ }^{15}$ Wawancara dengan Rabukit Damanik, M.Pd selaku mantan Kepala Sekolah SMA dan SMK Swasta Laksamana Martadinata Medan selama 20 tahun.

${ }^{16}$ Wawancara dengan Drs. Partoyo HS selaku mantan Sekretaris Dinas Pendidikan Kota Binjai selama 2 Tahun.

${ }^{17}$ Wawancara dengan Dr. Hadi Widodo, MA selaku Dosen Prodi Bimbingan Konseling STKIP Budidaya Binjai.
} 
pembelajaran agar tujuan yang hendak dicapai sesuai dengan harapan bersama. Pemahaman pentingnya peran guru dalam dunia pendidikan kepada masyarakat haruslah lebih dioptimalkan sehingga terlihat profesi guru adalah profesi yang mulia sebagai bagian dari mencerdaskan kehidupan bangsa sebagaimana dalam pembukaan UUD $1945 .^{18}$

Yulinda Dwinata, M.Pd mengatakan bahwa peran guru PPKN dan guru agama adalah amat penting dalam pembekalan pengetahuan dan spiritual dilingkungan sekolah. Faktor keluarga juga berdampak besar pada karakter siswa. Perhatian dan kasih sayang kepada anak sebagai peserta didik amatlah perlu dioptimalkan. Pengawasan orang tua juga merupakan faktor yang berpengaruh dalam mendidik, membina, mendewasakan, sehingga siswa mampu mengetahui berbagai hal positif dalam penerapannya. ${ }^{19}$

Arfida Melwana, S.Pd selaku orang tua yang memiliki anak yang sedang mengenyam pendidikan formal di kota Binjai mengatakan moral pada siswa sangatlah rendah sehingga rasa menghormati guru sebagai profesi yang mulia tidak dipahami oleh anak sebagai siswa. Perhatian yang kurang diperoleh oleh siswa dari lingkungan keluarga yang sangatlah minim menjadi salah satu faktor yang mempengaruhi karakter siswa. Rutinitas orang tua dalam kesehariannya dalam memberikan perhatian kepada anak sebagai peserta didik yang perlu dioptimalkan sebagai bentuk kepedulian orangtua dalam membangun pribadi anak dalam hal pendidikan non formal sebagai bentuk tanggung jawab sebagai orang tua dalam mendewasakan anak dalam ruang lingkup siswa guna menjadi manusia yang berkualitas. $^{20}$

Prof. Dr. Syaiful Sagala, S.Sos, M.Pd berpendapat tentang kasus penganiayaan guru SMAN 1 Torjun Sampang Jawa Timur merupakan suatu bentuk penyimpangan yang terjadi pada individu sebagai pelaku penganiayaan.

Hal tersebut dapat terjadi oleh beberapa faktor diantaranya kemampauan yang rendah oleh pelaku dalam memahami informasi yang diperoleh baik melalui

\footnotetext{
${ }^{18}$ Wawancara dengan Surya Wibawa, MH selaku dosen Prodi PPKN STKIP Budidaya Binjai.

${ }^{19}$ Wawancara dengan Yulinda Dwinata, M.Pd selaku Guru SMP Negeri 6 Binjai.

${ }^{20}$ Wawancara Arfida Melwana, S.Pd selaku orang tua melihat kasus yang terjadi dalam penelitian ini.
} 
interaksi yang terjadi dilingkungan keluarga, sekolah, dan masyarakat bahkan dalam pemanfaatan internet dalam kesehariaannya. berbagai hal negatif dapat timbul oleh perbuatan anak sebagai peserta didik, mulai dari tingkat kenakalan, penyimpangan, bahkan termasuk kedalam perbuatan kriminal sekalipun. Oleh karenanya semua komponen berperan serta dalam pembentukan karakter anak sebagai generasi muda khususnya dalam hal ini yakni sebagai peserta didik. Dalam ruang lingkup sekolah sebagai sarana tempat belajar oleh semua pihak, tidak hanya oleh tenaga pendidik bahkan juga peserta didik. Hal demikian yang harus ditanamkan dalam konsep pemikiran dalam menjadikan sekolah sebagai tempat menimba ilmu dan pengalaman, sehingga segala unsur tidak menimbulkan rasa individualisme yang sifatnya masiv sebagai bentuk karakter bangsa Indonesia yang majemuk. ${ }^{21}$

\section{PENUTUP}

\section{A. Kesimpulan}

1. Profesi guru sebagai tenaga pendidik adalah salah satu implementasi penerapan sistem pendidikan nasional dan tujuan pendidikan nasional, dimana berperan penting dalam membentuk karakter siswa sebagai peserta didik dalam membekali siswa dari aspek kognitif, afektif, dan psikomotorik guna menghasilkan sumber daya manusia yang cerdas secara intelektual maupun spiritual.

2. Pengaruh perkembangan ilmu pengetahuan dan teknologi yang belum mampu disaring oleh siswa sebagai peserta didik menjadi salah satu faktor yang menyebabkan peristiwa hukum diatas dapat terjadi.

\section{B. Saran}

1. Pemahaman pentingnya peran guru dalam upaya penerapan pembukaan UUD 1945 yaitu salah satunya ialah mencerdaskan kehidupan bangsa kepada masyarakat haruslah dioptimalkan agar lingkungan keluarga dapat memberikan pemahaman lebih lanjut kepada anak sebagai peserta didik

\footnotetext{
${ }^{21}$ Wawancara Prof. Dr. Syaiful Sagala, S.Sos, M.Pd selaku Ketua Dewan Pendidikan Sumatera.
} 
terhadap profesi guru dalam pembentukan sumber daya manusia yang berkualitas.

2. Pembekalan pengetahuan secara spritual lebih ditingkatkan, baik oleh lembaga pendidikan formal maupun non formal dalam menyikapi perkembangan pengtahuan secara umum dan teknologi yang terus menerus berkembang secara signifikan.

\section{DAFTAR PUSTAKA}

Chazawi , Adami, Pelajaran Hukum Pidana I, PT Raja Grafindo Persada, Jakarta, 2001.

Ilyas, Amir, Asas-Asas Hukum Pidana, Yogyakarta, Rengkang Education Yogyakarta dan Pukap Indonesia, 2012.

Poerwanto, Hari. Kebudayaan dan Lingkungan dalam Perspektif Antropologi. Yogyakarta: Pustaka Pelajar. 2010.

Soekanto, Soerjono, Faktor-Faktor Yang Mempengaruhi Penegakan Hukum, PT.Rajagrafindo Persada, Jakarta, 2012.

Tri Lestari Utami, Kekerasan Dalam Dunia Pendidikan, http://jurnalilmiahtp2013.blogspot.co.id/2013/12/kekerasan-dalam-duniapendidikan.html, diakses tanggal 03 April 2018.

Turmudi, Mengenali Kekerasan Dalam Pendididikan Dan Upaya Meniadakannya Atau Memperkecil Resiko Tindak Kekerasan, http://file.upi.edu/Direktori/FPMIPA/JUR._PEND._MATEMATIKA/1961 0112 87031-TURMUDI/F12-Final-Draft-Kekerasan_dalam_PendidikanTurmudi.pdf, diakses tanggal 03 April 2018. 